\title{
Serum Total and Lipid-Bound Sialic Acid Concentrations in Sheep with Natural Babesiosis
}

\author{
Y. DEGER, H. MERT, S. DEDE, F. YUR, N. MERT \\ Department of Biochemistry, Faculty of Veterinary Medicine, Yuzuncu Yil University, Van, Turkey \\ Received May 10, 2006 \\ Accepted July 9, 2007
}

\begin{abstract}
Deger Y., H. Mert, S. Dede, F. Yur, N. Mert: Serum Total and Lipid-Bound Sialic Acid Concentrations in Sheep with Natural Babesiosis. Acta Vet. Brno 2007, 76: 379-382.

The aim of this study was to determine the serum concentrations of total and lipid-bound sialic acid in sheep naturally infected with Babesia ovis before and after treatment. Thirty diseased sheep and ten control animals were used. Babesia infection was confirmed with Giemsa's staining of blood smears. Compared to the control animals $\left(1.351 \pm 0.100 \mathrm{mmol}^{-1} ; 0.385 \pm 0.001\right.$ mmol.1 $\left.1^{-1}\right)$, a marked increase of serum total and lipid bound sialic acid concentrations $(1.929 \pm$ $0.101 \mathrm{mmol} \cdot \mathrm{l}^{-1} ; 0.479 \pm 0.004 \mathrm{mmol} \cdot \mathrm{l}^{-1}$, respectively) was obtained in infected sheep $(p<0.05)$. One week after treatment, serum total and lipid bound sialic acid concentrations significantly decreased $\left(1.554 \pm 0.005 \mathrm{mmol} \cdot \mathrm{l}^{-1} ; 0.411 \pm 0.02 \mathrm{mmol}^{-1} \mathrm{l}^{-1}\right.$, respectively) $(p<0.05)$. Despite this decline, total and lipid bound sialic acid concentrations of treated animals were still significantly increased in sera compared to the control animals $(p<0.05)$. When the infected animals were treated with an antiparasitic drug (diminazene aceturate), the serum total and lipid bound sialic acid levels had a tendency to decrease to the normal ranges. It can be concluded that Babesia ovis infection induced marked and persistent elevations of serum total and lipid-bound sialic acid concentrations, suggesting that these indicators would indirectly promote the invasion and presence of the parasite in the host.
\end{abstract}

Sheep, Babesia ovis, sialic acids

Sialic acids are nine-carbon monosaccharides that link to the terminal galactose, $\mathrm{N}$ - acetylgalactosamine, or to other sialic acids in carbohydrate chains of glycoproteins or glycolipids (Corfield and Schauer 1982). Sialic acids usually occupy exposed terminal positions on the oligosaccharide chains of glycoconjugates and frequently serve as ligands for receptors such as selectins and siglecs, which mediate a variety of cell-cell adhesion processes in the inflammation and in the immune response (Kelm and Schauer 1997; Malykhy et al. 2001).

Babesia species are protozoan parasites that develop in the erythrocytes of vertebrate hosts and are transmitted transovarially and transstadially by ixodid ticks (Urquhart et al. 1996; Friedhoff 1988). The severity of the disease caused by these parasites, namely babesiosis, is related to the vertebrate host and protozoan species (Urquhart et al. 1996). Ovine babesiosis is the most important haemoparasitic tick-borne disease of small ruminants caused by Babesia ovis, Babesia motasi and Babesia crassa. These parasites are widespread in tropical and subtropical areas of the world (Uilenberg 2001). Babesia ovis is highly pathogenic especially in sheep, and causes severe infections that are charecterised by fever, anaemia, icterus and haemoglobinuria (Almeria et al. 2001).

Sialic acids are present in normal human and animal serum. It has been demonstrated that sialic acid concentrations are elevated in patients suffering from various diseases (Schutter et al. 1992; Wongkham et al. 2003). However, the effect of Babesia ovis infection on serum total and lipid-bound sialic acid content in sheep has not been reported previously.

Address for correspondence:

Dr. Yeter Değer

Department of Biochemistry, Faculty of Veterinary Medicine,

Yuzuncu Yil University

Van 65080, Turkey

Tel: +90 432 2251128
Fax: +90 4322251127
E-mail: ydeger65@hotmail.com
http://www.vfu.cz/acta-vet/actavet.htm 
Therefore, the aim of the present study was to examine if there is any relationship between babesiosis and the serum total and lipid-bound sialic acid concentrations.

\section{Materials and Methods}

Forty Akkaraman sheep with a body mass of 25 - 30, at the age of 4 - 5 years and localized in different regions of Van between June and August of 2005 were used as subjects for this study. Thirty sheep were infected naturally with Babesia ovis and ten control animals were clinically healthy. All the cattle included in this study submitted to clinical and parasitological examinations. Treatment of thirty infected animals was conducted with diminazene aceturate (Berenil ${ }^{\mathbb{R}}$ ) 7\% solution) once at a dose of $3.5 \mathrm{mg} / \mathrm{kg}$, intramuscularly. Blood samples of all animals were taken into plain and EDTA containing vacutainer tubes from the jugular vein. Samples were firstly taken at the onset of the disease during the disease season of babesiosis (June - August), then one week following the treatment of the diseased animal. At this time, the treated animals did not show any clinical signs of babesiosis. Serum samples were obtained after centrifugation at $1700 \mathrm{~g}$ for 15 minutes at room temperature, aliquoted and stored at $-20^{\circ} \mathrm{C}$ until used.

Serum total sialic acid concentration was determined by a method previously described by Sydow (1988). Lipid bound sialic acid concentration was determined by the method described by Katopodis et al. (1982). The amount of total and lipid bound sialic acid were determined by use of a standard curve developed from a standard sample of n-acetyl neuraminic acid.

EDTA-blood was used to prepare thin blood smears. Blood smears were fixed in methanol, stained with Giemsa and examined for the presence of blood protozoa.

The results were expressed as means \pm standard deviation. Duncan's test was used for statistical analysis, setting $p<0.05$ to establish statistically significant differences.

\section{Results}

Table 1. Serum total sialic acid and lipid-bound sialic acid concentrations in healthy sheep (control group) and naturally infected sheep with Babesia ovis (infected group) at the onset of the disease and one week after treatment by diminazene aceturate parasites (mean \pm S.D.)

\begin{tabular}{|l|c|c|c|}
\hline \multirow{2}{*}{ Indicators } & Control group $(\mathrm{n}=10)$ & \multicolumn{2}{|c|}{ Infected group $(\mathrm{n}=30)$} \\
\cline { 3 - 4 } & & During disease & After Treatment \\
\hline Total sialic acid $\left(\mathrm{mmol} \cdot \mathrm{l}^{-1}\right)$ & $1.351 \pm 0.100$ & $1.929 \pm 0.101^{*}$ & $1.554 \pm 0.005^{*}$ \\
\hline $\begin{array}{l}\text { Lipid-bound } \\
\text { sialic acid }\left(\mathrm{mmol} \cdot \mathrm{l}^{-1}\right)\end{array}$ & $0.385 \pm 0.001$ & $0.479 \pm 0.004^{*}$ & $0.411 \pm 0.02^{*}$ \\
\hline
\end{tabular}

* $(P<0.05)$

The biochemical findings obtained in the study are summarised in Table 1.

Blood smears prepared from the thirty diseased animals showed the presence of piroplasm of Babesia ovis in the red blood cells with different parasitaemia. On the other hand, no piroplasm was detected in control animals. After recovery (i.e. following the treatment), piroplasms were still detected in all infected animals by direct microscopic examination with very low degree of parasitaemia.

Mean serum total and lipid bound sialic acid concentrations of the diseased animals were significantly higher than in the control and treated animals $(p<0.05)$. A significant decline was observed in the serum total and lipid bound sialic acid concentrations of the treated animals $(p<0.05)$. Total sialic acid and lipid bound sialic acid concentrations of treated animals (one week after treatment) were still significantly increased in sera compared to the control animals $(p<0.05)$.

\section{Discussion}

This study was conducted to examine the effect of babesia infection on total and lipidbound serum sialic acid concentrations. Babesia infection induced a significant increase of total and lipid-bound serum sialic acid concentrations. Furthermore, these acid 
concentrations were significantly reduced after the treatment of the animals. Nevertheless, despite the significant decline in serum total and lipid bound sialic acid content following the treatment, their concentrations remained significantly elevated up to one week following the treatment. It is well known that after recovery, animals become carriers of the parasite (Kaufmann 1996) and such high concentrations of sialic acid were probably due to the carrier state of treated animals.

It is currently unknown how infection with Babesia ovis leads to the increase of serum sialic acid content. However, infections with various parasites such as leishmania (Chatterjee et al. 1998; Karagenç et al. 2005), and trypanosoma (Eslevo et al. 1982; Olaniyi et al. 2001) are also associated with elevated serum sialic acid concentrations. It was reported that the serum total and lipid-bound sialic acid concentrations were found to be significantly higher in cattle infected with blood parasites (theileria, anaplasma) as compared to the control group (Ertekin et al. 2000).

Host sialic acids were reported to play an important role in the erythrocyte invasion by babesia parasites (Yokoyama et al. 2006). Total sialic acid plays a role as a host receptor in the erythrocyte invasion by Babesia bovis, and treatment prevented the increase of sialic acid (Gaffar et al. 2003). In addition, Okamura et al. (2005) observed that sialic acid residues on host RBC play important roles in the erythrocyte infections by Babesia caballi and Babesia equi and cause a significant increase in its concentration. Conversely, sialic acid deficiency in the erythrocytes of infected cattle with Babesia bovis has been reported by Commins et al. (1988).

Sialic acid could modulate biological cell-cell interactions in two non-mutually exclusive ways. First, sialic acid could mask the underlying sugar chains (i.e. lactosaminic sequences), hindering then from interacting with galactose-specific lectins (galectins) (Razi and Varki 1998). Second, sialic acid would directly interact with specific sialic acid-binding lectins (siglecs) (Dall'olio 2000). Therefore, increased contents of sialic acid would interfere with the attachment of sporozoites on host cells, or promote the invasion of erythrocytes by merozoites.

Our finding showed that natural infection of sheep with Babesia ovis leads to significant increases of serum total and lipid-bound sialic acid concentrations, suggesting that sialic acids would indirectly promote the invasion and persistence of parasite in the host.

\section{Koncentrace celkové a na tuk vázané kyseliny sialové v séru ovcí přirozeně infikovaných babesiózou}

Cílem této studie bylo určit koncentrace celkové a na tuk vázané kyseliny sialové v séru ovcí přirozeně infikovaných Babesia ovis před a po léčbě. Použito bylo třicet nemocných a deset kontrolních ovcí. Infekce babesiemi byla prokázána Giemsovým barvením krevních nátěrů. Ve srovnání s kontrolními zvíraty $\left(1.351 \pm 0.100 \mathrm{mmol} \cdot \mathrm{l}^{-1}\right.$; $0.385 \pm 0.001 \mathrm{mmol} \cdot \mathrm{l}^{-1}$ ) byly u infikovaných zvířat zaznamenány výrazně vyšší koncentrace celkové a na tuku vázané kyseliny sialové $\left(1.929 \pm 0.101 \mathrm{mmol} \cdot \cdot^{-1} ; 0.479 \pm 0.004\right.$ $\left.\mathrm{mmol} \cdot \mathrm{l}^{-1}\right)(p<0,05)$. Jeden týden po léčbě tyto koncentrace výrazně klesly $(1.554 \pm 0.005$ mmol. $\left.\mathrm{l}^{-1} ; 0.411 \pm 0.02 \mathrm{mmol} \cdot \mathrm{l}^{-1}\right)(p<0,05)$. Ačkoliv koncentrace celkové a na tuk vázané kyseliny sialové $\mathrm{v}$ séru léčených zvířat klesly, byly ve srovnání s kontrolními zvíraty stále signifikantně zvýšené $(p<0,05)$. Když byla infikovaná zvírata léčena antiparazitiky, měly koncentrace celkové a na tuk vázané kyseliny sialové v séru tendenci klesnout k fyziologickým hodnotám. Z výsledků pokusu vyplývá, že infekce Babesia ovis indukovala výrazné a stálé zvýšení koncentrace celkové a na tuk vázané kyseliny sialové v séru, což naznačuje, že tyto ukazatele by mohly nepř́mo odhalovat infekci a přítomnost parazita $v$ hostiteli. 


\section{References}

ALMERIA S, CASTELLA J, FERRER D, ORTUNO A, ESTRADA-PENA A, GUTIERREZ JF 2001: Bovine piroplasm in Minorca (Balaric Island Spain): a comparison of PCR-based and light icroscopy detection. Vet Parasitol 99: 249-259

CHATTERJEE M, SHARMA V, MANDAL C, SUNDAR S, SEN S 1998: Identification of antibodies directed against $\mathrm{O}$-acetylated sialic acids in visceral leishmaniasis: its diagnostic and prognostic role. Glycoconjugate J 15: 1141-1147

CORFIELD AP, SCHAUER R 1982: Occurrence of Sialic Acids. In: SCHAUER R (Ed.): Sialic acids. Chemistry, metabolism and function. New York: Springer-Verlag Wien, pp. 5-50

DALL'OLIO F 2000: The sialyl-2,6-lactosaminyl-structure: Biosynthesis and functional role. Glycoconjugate J 17: 669-676

ERTEKIN A, KELEŞ I, EKIN S, KARACA M, AKKAN HA 2000: An investigation on sialic acid and lipidbound sialic acid in animals with blood parasites. YYU Vet Fak Derg 11: 34-35

ESLEVO K, SAROR DI, ILEMOBADE AA, HALLAWAY MH 1982: Variation in erythrocyte surface and free serum sialic acid concentrations during experimental Trypanosoma vivax infection in cattle. Res Vet Sci 32: $1-5$

GAFFAR FR, FRANSSEN FF, VRIES E 2003: Babesia bovis merozoites invade human, ovine, equine, porcine, and caprine erythrocytes by a sialic acid-dependent mechanism followed by developmental arrest after a single round of cell fission. Int J Parasitol 33: 1595-1603

KARAGENÇ T, ILHAN Ç, KARGIN KIRAL F, SEYREK K, BILDIK A, EREN H 2005: Detection of serum total sialic acid in cattle with natural tropical theileriosis. Rev Med Vet 156: 578-582

KATOPODIS N, HIRSHAUT Y, GELLER NL, STOCK CC 1982: Lipid-associated sialic acid test for the detection of human cancer. Cancer Res 42: 5270-5275

KAUFMANN J 1996: Parasitic Infections of Domestic Animals. A Diagnostic Manual. Birkhauser Verlag, Basel, Boston, Berlin, 423 p.

MALYKHY YN, SCHAUER R, SHAW L 2001: N-Glycolylneuraminic acid in human tumors. Biochimie 83: 623-634

OKAMURA M, YOKOYAMA N, WICKRAMATHILAKA NP, TAKABATAKE N, IKEHARA Y, IGARASHI I 2005: Babesia caballi and Babesia equi: implications of host sialic acids in erythrocyte infection. Exp Parasitol 110: 406-411

OLANIYI MO, TAIWO VO, OGUNSANMI AO 2001: Haematology and dynamics of erythrocyte membrane sialic acid concentration during experimental Trypanosoma congolense and T. Brucei infection of sheep. J Appl Anim Res 20: 57-64

RAZI N, VARKI A 1998: Masking and unmasking of the sialic acid-binding lectin activity of CD22 (Siglec-2) on B lymphocytes. Proc Nat Acad Sci USA 95: 7469-7474

SCHUTTER EM, VISSER JJ, VAN KAMP GJ, MENSDORFFPOUILLY S, VAN DICK M, HIGERS J, KENEMANS P 1992: The utility of lipid-associated sialic acid (LASA or LSA) as a serum marker for malignancy. A review of the literature. Tumor Biol 13: 121-132

SYDOW G, WITTMANN W, BENDER E, STARICK E 1988: The sialic acid content of the serum of cattle infected with bovine leukosis virus. Arch Exp Vet Med 42: 194-197

UILENBERG G 2001: Babesiosis. In: SERVISE MV (Ed.): Encyclopaedia of Arthropod-transmitted Infection of Man and Domestic Animals, CABI Publishing, Wallinford, pp. 53-60

URQUHART GM, ARMOUR J, DUNCAN JL, DUNN AM, JENNINGS FW 1996: Veterinary Parasitology, $2^{\text {nd }}$ ed., Blackwell Science Inc., Cambridge, 307 p.

WONGKHAM S, BHUDHISAWASDI V, CHAU-IN S, BOONLA C, MUISUK K, KONGKHAM S, WONGKHAM C, BOONSIRI P, THUWAJIT P 2003: Clinical significance of serum total sialic acid in cholangiocarcinoma. Clin Chim Acta 327: 139-147

YOKOYAMA N, OKAMURA M, IGARASHI I 2006: Erythrocyte invasion by babesia parasites: Current advances in the elucidation of the molecular interactions between the protozoan ligands and host receptors in the invasion stage. Vet Parasitol 138: 22-32 